\title{
Poverty, Welfare and Assessing the Impact of Productive Zakat Distribution
}

\author{
J umi Herlita*, Restu Khaliq \\ UIN Antasari Banjarmasin \\ Email: jumiherlita@uin-antasari.ac.id
}

\begin{abstract}
Zakat is an essential Islamic economic tool to mobilize assets to alleviate poverty and generate welfare. This paper discusses the relationship between zakat, primarily productive zakat, poverty, and welfare from the Islamic perspective. Because of the potential for extraordinary zakatcollection, it is expected that the distribution of zakat will have a tremendous impact on improving the welfare of the mustahiq. It is imperative to measure the impact of zakat distribution on mustahiq, especially when using appropriate analysis. CIBEST is an analytical tool capable of measuring these impacts from two viewpoints: material and spiritual perspectives. Zakat collection organizations and academics should utilize this analytical tool more to evaluate zakat distribution programs.
\end{abstract}

KEYWORDS: Poverty, Productive zakat, Welfare

\begin{abstract}
ABSTRAK
Zakat adalah alat ekonomi Islam yang penting untuk memobilisasi aset guna mengentaskan kemiskinan dan menciptakan kemakmuran. Tulisan ini membahas hubungan antara zakat, terutama zakat produktif, kemiskinan, dan kesejahteraan dalam perspektif Islam. Karena potensi penghimpunan zakat yang luar biasa, diharapkan penyaluran zakat akan berdampak signifikan bagi peningkatan kesejahteraan para mustahik. Sangat penting untuk mengukur dampak distribusi zakat pada mustahik, terutama jika menggunakan analisis yang tepat. CIBEST adalah alat analisis yang mampu mengukur dampak ini dari dua sudut pandang: perspektif material dan spiritual. Organisasi pengumpul zakat dan akademisi harus lebih memanfaatkan alat analisis ini untuk mengevaluasi program distribusi zakat.
\end{abstract}




\section{Introduction}

The economic contraction experienced by various parts of the world resulting from the COVID-19 pandemic has caused multi-dimensional problems. The production sector in Indonesia experienced a slowdown which boosted the number of unemployed. This phenomenon has linearity with the number of poor people continuing to grow. According to the Central Statistics Agency acknowledged as Badan Pusat Statistik (2021), the number of poor people reached 27.55 million people in September 2020, increasing 1.13 million people from March 2020. To reduce or eliminate poverty requires hard work that all components of the nation must support. In Islam, one of the efforts to reduce and eradicate poverty is zakat which functions as equal distribution of wealth.

Zakat could be distributed in a consumptive or productive method by zakat management organizations, either the National Amil Zakat Agency (Baznas) or other zakat management organizations. If giving zakat is to meet the basic needs of mustahiq, then zakat is distributed in a consumptive practice. Meanwhile, if giving zakat is as business capital utilized to fit their own living needs and enhance the quality of life to switch status to muzakki, then zakat is distributed productively (Pusat Kajian Strategis Baznas, 2020).

Zakat is a critical Islamic economic tool to mobilize assets for economic growth, poverty alleviation, and empowerment of eight specific groups in society (Saad \& Haniffa, 2014). The global potential of zakatcollection, referring to a study from the Islamic Research and Training Institute (IRTI) of the Islamic Development Bank (ISDB), stands at approximately US $\$ 50$ billion to US $\$ 600$ billion per year. On the reverse side, the total amount of zakatfunds collected is around US $\$ 10$ billion to US $\$ 15$ billion annually (WZF Research and Development in Collaboration with BAZNAS Center of Strategic Studies, 2021). Imagine if the potential of zakat globally could be distributed to people in need and have an impact that is expecting to improve economic conditions.

Most of the research on zakat takes the topic of zakat distribution, administration/collection of zakat, zakat and poverty alleviation, and zakat and Islamic microfinance (Kasri, 2017; Kasri \& Ahmed, 2015; Sari, 2013; Shaikh, 2017). One vital topic is evaluating to measure the extent to which zakat can positively impact mustahiq. Because of this perspective, the main objective of this paper is 
to emphasize the importance of assessing the impact of productive zakat distribution.

\section{Literatur Review}

\section{Zakat and Productive Zakat}

Growth, cleanness, and purity of wealth are the meaning of zakat from an etymology perspective. It said growth because the design of zakatpayment is to empower the poor to gain in wealth and spirit (AI-Qadrawi, 1973). While zakatsaid as cleanness and purity because zakat payment purifies and cleans both the wealth and the heart of the zakatpayer, prepares him to sacrifice for the cause of Allah (Shad, 1986) as well as the Holy Quran mentioned in Surah At-Tawbah verse 103:

"Take charity from their possessions to cleanse them and purify them thereby, and bless them. Indeed, your blessing is a comfort to them, and Allah is allhearing, all-knowing."

Furthermore, the Prophet Muhammad (PBUH) sent Muadz to Yemen and said: "Verily Allah has obligated (zakat) for them, their wealth is taken from the rich among them and returned to the poor in among them." (Jajuli, 2016) Meantime, according to terminology (syara), zakat is an activity (worship) to issue some property or main food ingredients per the provisions of the Shariagiven to specific people at particular times with certain levels (Anonimus, 1997). Muslims accept the concept that Allah is the reservoir of all blessing and wealth, which $\mathrm{He}$ distributes to anyone He pleases (Quran 17:29). As a result, Allah is the actual proprietor of the earth's wealth. The zakat payer seeks Allah's pleasure and expresses his gratitude to Him by contributing a portion of his wealth (zakat) (Samad \& Glenn, 2010). Hafidhuddin (2002) defines zakatas part of wealth subject to several conditions that Allah SWT has stated as an obligation for its owner to be given to those entitled to receive zakat, which is also subject to some conditions.

Zakat is referenced 82 times in the Quran, and it is also cited in hadiths that are further elaborated by Muslim scholars' ijtihad and are thus declared obligatory for Muslims fulfill (Ali, 2006); this fact depicted that zakat has a crucial position, function, and role. While the word al-zakat, when appended by the word "al-ita" 
(to give), then it means that it concerns the level of wealth that Muslims must grant (Abdullah, 2002). Here are some verses of the Qur'an that explain zakat.

\section{Al-Baqarah verse 43}

"And maintain the prayer, and give the zakat, and bow along with those who bow [in prayer]."

\section{At-Tawbah verse 60}

"Charities (zakat) are only for the poor and the needy, and those employed to collect them, and those whose hearts are to be reconciled, and for [the freedom of] the slaves and the debtors, and in the way of Allah, and for the traveller. [This is] an ordinance from Allah, and Allah is all-knowing, all-wise."

\section{Al-Mu'minun verses 1-4}

"Certainly, the faithful have attained salvation (1) those who are humble in their prayers (2), who avoid vain talk (3), who carry out their [duty of] zakat (4)."

The foundation of the zakat payment has numerous goals, notably eradicating poverty and ensuring socioeconomic justice; protecting riches from the jealously of others, particularly the poor; purifying wealth and removing stringiness; and remaining grateful to God for His bounty to him (Samad \& Glenn, 2010). Some lessons of zakat distribution for mustahiq are (DEKS Bank IndonesiaP3EI FE UII, 2016):

1. Zakat protects and preserves property from the eyes and hands of sinners and thieves.

2. Zakat can help the poor and needy; zakat can encourage them to work with enthusiasm and achieve a decent life.

3. Zakatpurifies the soul from illness and miserliness. It also trains a believer to be a giver and generous.

4. Zakat will grow wealth, not make the payer poor.

5. Zakat is required as an expression of gratitude for the blessings of wealth that have been entrusted to someone. 
There are two categories of zakat, firstly, zakat al-fitr is a one-time contribution made at any time during Ramadan in the Muslim Hijri calendar year before Eid Al-Fitr prayers among Muslims, regardless of their age, rank, or wealth, are obliged to pay this kind of zakat except they do not have sufficient food to eat. The other one, zakat al-mal refers to zakat on wealth, or an annual payment depending on the amount of wealth owned by a Muslim individual or organization who has met the nishab (minimum taxable amount) and Haul (minimum taxable amount) requirements in one Muslim Hijri calendar year. Zakat al-mal is classified into zakat on business, rental income, personal income, savings, gold, silver, stocks, animals, and crops, among other things (Veen, 2009). The distribution of zakathas evolved; from its beginnings as a means of meeting needs (consumptive), it has now progressed to zakat as a source of productive funds that can help the economy develop (Winoto \& Pujiyono, 2011). Because zakat is given to mustahiq as a provision for the application of productive zakat, this development in the form of business capital, the ultimate goal of zakat is to turn a mustahiq into a muzakki (Hasbiyah, 2017; Rini et al., 2013).

Only the eight groups of people should receive zakat, among the zakat mustahiq who are entitled to receive productive zakat are the poor (fuqara), the needy (masakin), the administrators of zakat (amil), the converts (muallaf), but what is prioritized over them the poor (fuqara) and the needy (masakin). Besides they only get consumptive zakat or certain needs such as those in bondage (riqab), those in debt (gharimin), those in the cause of God (fi sabilillah), and the wayfarer (Ibnu sabil).

Observing the urgency of the importance of productive zakat, several creative and innovative models of zakat distribution in modern times have been developed, including first, a model with an in-kind system, namely zakatfunds are given in the form of production tools needed by mustahiq who want to produce, whether they are just starting a business or developing an existing business (Muhaom, 2010). Second, the model with the al-qard al-hasan system, which is a form of loan that stipulates the absence of a particular rate of return/profit sharing on the return of the loan principal (Mufraini, 2006). The last, the mudarabasystem. This system is almost the same as al-qard al hasan. The difference lies in the division of profit-sharing from the business between mustahiq and amil(Mufraini, 
2006).

\section{Poverty}

Poverty remains the main issue faced by Islamic researchers recently, and interestingly this term is no one-size-fits-all definition because of the differences in many aspects (Beik \& Arsyianti, 2015). Poor can be interpreting as a person who has nothing, or has something but is not sufficient, or a person who is quelling by poverty, and some say, poor is a person who does not have something that can be meet their daily needs (Mandzur, 2009).

Maqasid al shariah is the main discussion on poverty from an Islamic perspective classified into five major categories by classical Islamic scholars Imam al-Ghazali. Those are the protection of life, religion, wealth, reason, and progeny as fundamental requirements of life (Aisyah, 2014; Ummulkhayr, 2018). Further, Imam al-Shatibi classified the maqasid into three main categories; essentials (daruriyyat), supporting (hajiyyat), and embellishment (tahsiniyyat) (Beik \& Arsyianti, 2015). Imam Ghazali further divided human needs in the hierarchy into necessities, conveniences, and refinements (Aisyah, 2014; Anas, 1980). In simple terms, necessities are the minimum basic needs that everyone must meet and are usually the state's responsibility, while the needs of convenience are not vital but needed for the support of life. The needs for refinements are things that can make life more pleasurable.

Being a balance religion, Islam views poverty as a social and ideological problem because of its effects on society and its socio-religious obligation to Allah (Aisyah, 2014). There is a Qur'an explanation about the background of the causes of the poverty problem, which is different from the analysis of social experts. If they split the causal factors and forms of poverty into three, natural poverty, cultural poverty, and structural poverty, the Qur'anic cues talk about the causes of poverty experienced by humankind such as (Hakim \& Syaputra, 2020):

1. Laziness and effortlessness in working.

2. Extravagant.

3. Miserly and hesitant to share with others.

4. Greedy in the search for treasure, causing earth damage. 
5. The system and structure built in a society far from the values of justice and full of discrimination and exploitation.

The manifestation of being earnest in trying is evident in the story of Maryam giving birth to Prophet Isa. Allah order Mary to stagger the base of the date palm tree so that its ripe fruit fell (Qur'an 19: 22-26). The principle that the Qur'an wants to convey through this story is for humans to have confidence in their abilities and try to actualize their potential, even if there are only remnants (Kallang, 2020), On the antithesis, if what happens is laziness, it will become a problem. Besides that, there are many commands in the Qur'an so that Muslims want to work and try.

Furthermore, a wasteful attitude can cause the perpetrator to fall into the poverty problem because Allah forbids Muslims to be extravagant, waste wealth, and be excessive. Many verses of the Qur'an command to share and give charity reasonably, as well as prohibitions to be stingy and not too excessive, as in the Qur'an surah Al-Isra verse 29, surah An-Nahl verse 27 surah Al-Furqan verse 67 (Hakim \& Syaputra, 2020).

The Qur'an instructs humans to avoid all forms of activities that can damage the environment in the surah Ar-Rum verses 41-42. If the environmental damage is severe, it will not be straightforward to restore its condition (Munadi \& Kaslam, 2020). Furthermore, poverty also arises because the system applies to a society that causes a person or group of people to be powerless in breaking away from the shackles of poverty (Hakim \& Syaputra, 2020). This case can be discerned in several verses in the Qur'an when describing the stories of the previous people, especially the resistance of the prophets to the oppressor rulers of each era, such as the story of the prophet Moses who had to face the tyrannical king Pharaoh to liberate him and Bani Israel (Qur'an 7: 127).

Poverty and inequality are sure things we see in the world but Allah Almighty created inequality for a purpose. Islam never asks people to relent to poverty and inequality but rather inspires its followers to exert efforts to minimize the disparities through legitimate Shariah-compliant means (Bashir, 2018). Muslims are motivated to uplift their poverty by being productive and participating in economic activities that produce income to achieve welfare. 


\section{Welfare}

"Catera" is a Sanskrit word that means umbrella. In the context of welfare, this word has the meaning of a prosperous person whose life is safe and peaceful, and spiritual because he is free from poverty, ignorance, fear, or dismay (Fahrudin, 2012). Some people think that welfare is associated with the concept of quality of life, a picture of a good life state. The definition of "quality of life "from the World Health Organization is a person's perception of his life in society in culture and value systems related to goals, expectations, standards, and concerns about life. This concept gives a broader meaning because it is including the individual's physical condition, psychology, independence level, and social relationship with the environment (Fahrudin, 2012).

Moreover, in conventional economics, welfare as a goal is pure materialist sense that completely denies the spiritual connection, perhaps with a slight hint of spirituality. Suppose the materialist and hedonic concepts define welfare; it will emphasize excellence in fulfilling self-interest and maximizing wealth, physical enjoyment, and lust satisfaction (Chapra, 2001). This understanding has proven to lead to failures in delivering development to achieve welfare. Therefore, an alternative concept of welfare emerged, which refers to the values of Islamic sharia teachings. When the monetary economic crisis hit the world, economic institutions in developing countries that implemented the sharia mechanism were proven to survive, and even some were able to grow and develop (Purwana, 2014). So starting from this success, many studies began to be made about the concept of welfare based on Islamic sharia economics.

Furthermore, economic activities, both individually and in society, must be based on the benefit of humankind from the Islamic perspective. The purpose of life is not consuming, but consumption is a consequence of life. Consumption activities both because of wants and needs based on the ability of both soul, body, and finance (Putong, 2007). In brief, the welfare desired by Islamic teachings is holistic and balanced, and the second is welfare in this world and the hereafter. Holistic and balanced welfare includes both material and spiritual dimensions and includes both individual and social dimensions. Meantime, welfare in the world and the hereafter, because humans will also live in the hereafter. If this ideal condition in the world is un-accomplish, then welfare in the 
hereafter is, of course, prioritized (Pusparini, 2015).

The Qur'an has alluded to indicators of welfare in surah al-Quraish verses 34 , that is to say, worshiping Allah (owner) of the Kaaba, eliminating hunger, and eliminating fear (Sodiq, 2015). The first indicator depicts mental development, which shows that if someone has fulfilled all welfare indicators based on material aspects, it does not guarantee that the owner will endure peace. Furthermore, the second indicator reveals that in Islamic economics, the fulfillment of human consumption needs, which is one indicator of welfare, should be adequate to eliminate hunger and not be excessive, let alone hoarding to extract supreme wealth. At the same time, the last indicator is the loss of fear, which represents the creation of a sense of security, comfort, and peace. If various kinds of crimes such as robbery, rape, murder, theft, and other crimes occur a lot in the community, it shows that people do not perceive peace, comfort, and peace in life, or in other words, people do not possess welfare (Sodiq, 2015).

Zakat is an undisputed tool to attain the welfare of the Islamic perspective. If managing zakat properly, it can heighten the welfare of mustahiq, especially when zakat given to mustahiq is not spent directly on the consumption of particular needs but are developed and utilized to fund their businesses that with these efforts, they can fit the necessities of life continuously. In many countries today, there are zakat management institutions that collect and distribute zakat proceeds. These activities could maximize benefits for the poor, including distributing agricultural seeds, building houses, providing production equipment, capacity building, and human resource training programs (Farooq, 2008). Programs like this have proven to be effective in helping the poor be more independent and productive to achieve prosperity, and globally, zakatis now part of poverty reduction strategies in many countries.

\section{Discussion}

\section{Assessing the impact of productive Zakat distribution}

As one of the five pillars of Islam, zakat could only play an influential role in poverty reduction if zakat integrates with the strategy and development programs nationally and uses a more formidable percentage of productive zakat to enhance the use of zakat in poverty reduction (Aisyah, 2014). Productive zakat 
utilization has the notion of careful planning and implementation, such as examining the roots of poverty, lack of working capital, and dearth of employment opportunities (Dimyati, 2017). Because of these problems, it is necessary to have a plan that can develop productive zakat.

The utilization of zakat must have a positive impact on mustahiq, both economically and socially. The mustahiq must be genuinely independent and live decently from the economic side, while mustahiq must live on par with other communities from the social side (Dimyati, 2017). It means that zakat is not only distributed for consumptive matters but more for productive and educational purposes.

After the distribution of the productive zakat process is complete, then what is no less critical is the supervision of the mustahiq who receive the productive zakat, lest the funds are misused or not used as business capital (J ajuli, 2016). This control is essential considering that this program can be successful when the mustahiq business is advanced and can return the zakat funds.

The supervision model for the circulation of productive zakat funds can also be in the form of business assistance, a kind of consultant who will direct the mustahiq in running their business. This mentoring model should also not only focus on the business it manages but also be able to assist and provide input in terms of spiritual mustahiq (J ajuli, 2016). The meeting groups holding between productive zakatrecipients and zakatmanagers valuable as a moment to provide religious lectures and alleviate worldly poverty and alleviate them from spiritual poverty.

No matter how well the zakat program, including productive zakat, is implemented, without evaluating the program's success, zakat management organizations cannot conclude the program's quality, especially if there is no appraisal of the impact felt mustahiq. Poverty is usually assessed from a material perspective only. Therefore, it is essential to make sure mustahiq can get holistic and balanced welfare that includes both material and spiritual dimensions, as outlined previously.

In this case, an evaluation instrument that appraises poverty's material and spiritual aspects is highly needed. Beik and Arsyianti (2015) have endeavored to construct a tool of analysis related to poverty and welfare from material and 
spiritual perspectives in the form of the CIBEST (Center of Islamic Business and Economic Studies) index consisting of welfare index, material poverty index, spiritual poverty index, and absolute poverty index.

In the CIBEST model, Beik and Arsyianti (2015) then divide the household condition into four feasible circumstances:

1. A household can fulfill both of these needs, both materially and spiritually, called a prosperous household. This household condition means that the family's income is above the material poverty line, and the spiritual score is higher than the spiritual poverty line.

2. A household is only able to meet spiritual needs but cannot meet material needs. Such households are in a condition of material poverty.

3. A household can only meet material needs but cannot meet their spiritual needs. This household condition is called the spiritual poverty group.

4. A household is unable to meet both of these needs, material and spiritual needs.

Furthermore, based on this structure, Beik and Arsyianti set the CIBEST quadrant:

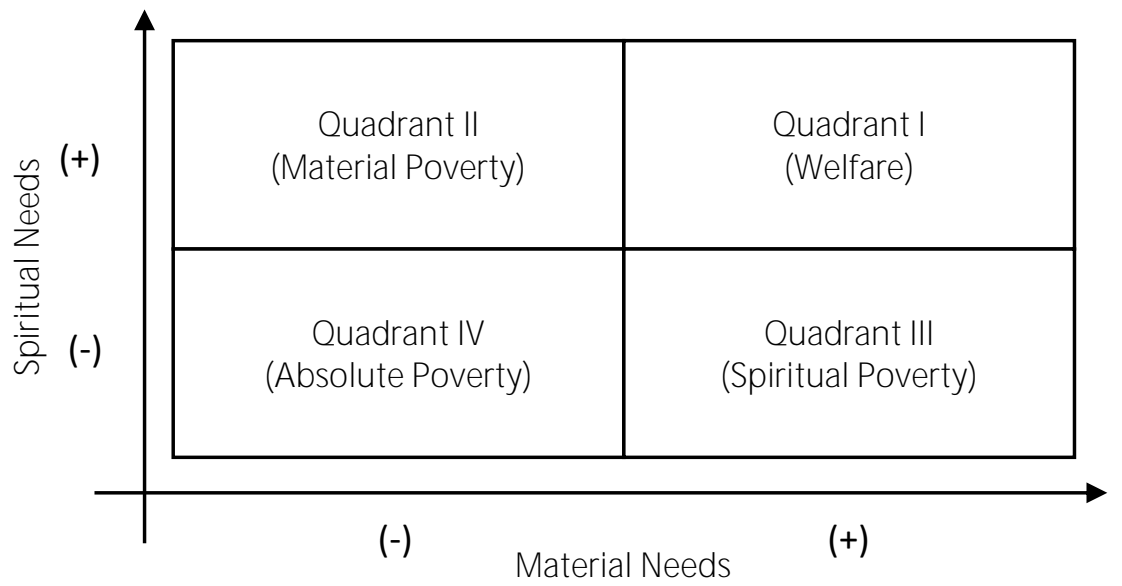

Figure 1. CIBEST Quadrant

Source: Beik and Arsyianti (2015) 


\section{Conclusion and Suggestion}

With the CIBEST formulation measuring the impact of productive zakat on mustahiq, it is expected that the zakat program is appropriately channeled and the effectiveness of the zakat program adequately measured. Unfortunately, research related to the impact of zakat using this construct formulation has not yet been researched among academics. It is highly recommended that all zakat stakeholders and researchers utilize this CIBEST construct to measure the zakat productive impact on mustahiq.

\section{References}

Abdullah, T. (2002). Ensiklopedi Tematis Dunia Islam (Jilid 2). PT Ichtiar Baru Van Hoeve.

Aisyah, M. (2014). The role of zakat and binary economics in poverty reduction. EsensiJurnal Blsnis dan Manajemen, 4(2), 178-197.

Al-Qadrawi, Y. (1973). Fiqh al Zakat (2nd ed.). Mu'assasat al Risalah. Ali, M. D. (2006). Sistem Ekonomi Islam Zakat dan Wakaf. UI Press.

Anas, Z. (1980). Islamic economies: An approach to human welfare. In A. Khurshid (Ed.) Studies in Islamic Economics. International Centre for Research in Islamic Economics.

Anonimus. (1997). Pedoman Manajemen Zakat. BAZISKAF PT TELKOM Indonesia.

Badan Pusat Statistik. (2021). Persentase Penduduk Miskin September 2020 Naik Menjadi 10,19 persen. www.bps.go.id. https://www.bps.go.id/pressrelease/2021/02/15/1851/persentasependuduk-miskin-september-2020-naik-menjadi-10-19-persen.html

Bashir, A. H. (2018). Reducing poverty and income inequalities: Current approaches and Islamic perspective. Journal of King Abdulaziz University, Islamic Economics, 31(1), 93-104. https://doi.org/10.4197/Islec.31-1.5

Beik, I. S., \& Arsyianti, L. D. (2015). Construction Of CIBEST Model as Measurement of Poverty and Welfare Indices From Islamic Perspective. Al-Iqtishad:J Jurnal IImu Ekonomi Syariah, 7(1), 87-104. https://doi.org/10.15408/aiq.v7i1.1361

Chapra, U. (2001). The Future of Economics: an Islamic Perspective, diterjemahkan oleh: Amdiar Amir, dkk. Jakarta: Shari ah Economics and Banking Institute. (A. Amir \& dkk (ed.); Terjemah). Shari ah Economics and Banking Institute.

DEKS Bank Indonesia-P3EI FE UII. (2016). Seri Ekonomi Dan Keuangan Syariah: Pengelolaan Zakat Yang Efektif: Konsep Dan Praktik Di Beberapa Negara. DEKS Bank Indonesia.

Dimyati. (2017). Urgensi Zakat Produktif di Indonesia. 2(2), 189-204.

Fahrudin, A. (2012). Pengantar Kesejahteraan Sosial. Refika Aditama.

Faroog, M. O. (2008). The Challenge of Poverty and the Poverty of Islamic Economics. Journal of Islamic Economics, Banking and Finance, 4(2), 35-58. Hafidhuddin, D. (2002). Zakat dalam perekonomian modern. Gema Insani.

Hakim, L., \& Syaputra, A. D. (2020). Al-Qur'an dan Pengentasan Kemiskinan. Jurnal 
IImiah Ekonomi Islam, 6(3), 93-110. https://doi.org/10.29040/jiei.v6i3.1310 Hasbiyah, W. (2017). Peran Zakat Produktif dengan Pemberian Modal Usaha dalam Meningkatkan Ekonomi Umat. 8(1), 93-110.

Jajuli, S. (2016). Pendayagunaan Zakat Produktif (Studi BAZ Kabupaten Sukabumi Jawa Barat). Misykat al-Anwar Jurnal Kajian Islam dan Masyarakat, 27(1).

Kallang, A. (2020). Konteks Miskin dalam Teks Al Quran. Jurnal Al Walid, 1(2), 171180.

Kasri, R. A. (2017). Management of Zakat Distribution: Empirical Evidence From Indonesia. AFEBI Islamic Finance and Economic Review, 2(02), 1. https://doi.org/10.47312/aifer.v2i02.109

Kasri, R. A., \&Ahmed, H. (2015). Assessing socio-economic development based on Maqāșid al-Sharīah principles: Normative frameworks, methods and implementation in Indonesia. Islamic Economic Studies, 23(1), 73-100.

Mandzur, I. (2009). Lisanul-'Arab, Juz. 3. Dar 'Ilmiah.

Mufraini, A. (2006). Akuntansi Dan Manajemen Zakat. Kencana.

Muhaom, F. (2010). Model-Model Kreatif Distribusi Zakat. Ijtihad, Jurnal Wacana Hukum Islam Dan Kemanusiaan, 10(1), 35-51.

Munadi, R., \& Kaslam. (2020). Etika Pengelolaan Hutan dalam Perspektif Al Qur'an. Tafsere, 8(2), 59-83.

Purwana, A. E. (2014). Kesejahteraan Dalam Perspektif Ekonomi Islam. Justicia Is/amica, 11(1). https://doi.org/10.21154/justicia.v11i1.91

Pusat Kajian Strategis Baznas. (2020). Official News Hasil Pengkuran Kaji Dampak Zakat 2020.

Pusparini, M. D. (2015). Konsep Kesejahteraan Dalam Ekonomi Islam (Perspektif Maqasid Asy-Syari'ah). Islamic Economics Journal, 1(1), 45-60.

Putong, I. (2007). Economics: Pengantar Mikro dan Makro. Mitra Wacana Media.

Rini, N., Huda, N., Mardani, Y., \& Putra, P. (2013). Peran Dana Dalam Mengurangi Ketimpangan Pendapatan dan Kemiskinan. Ekuitas: Jurnal Ekonomi dan Keuangan, 171), 108-127.

Saad, R. A. J ., \& Haniffa, R. (2014). Determinants of zakat (Islamic tax) compliance behavior. Journal of Islamic Accounting and Business Research, 5(2), 182193.

Samad, A., \& Glenn, L. M. (2010). Development of Zakat and Zakat coverage in monotheistic faiths. International Journal of Social Economics, 37(4), 302315. https://doi.org/10.1108/03068291011025264

Sari, M. D. (2013). Review on Indonesian Zakat Management and Obstacles. Social Sciences, 2(2), 76. https://doi.org/10.11648/j.ss.20130202.18

Shad, A. R. (1986). Zakat and Ushr. Kazi.

Shaikh, S. A. (2017). Poverty alleviation through financing microenterprises with equity finance. Journal of Islamic Accounting and Business Research, 8(1), 87-99.

Sodiq, A. (2015). Konsep Kesejahteraan Dalam Islam. Equilibrium, 3(2), 380-405.

Ummulkhayr, A. (2018). Internationalization of Zakat Management for Poverty Alleviation among Muslims in the 21st Century. Journal of Business Management and Accounting, 8(1), 1-15.

Veen, R. C. (2009). Charitable Giving in Islam, Islamic Relief Worldwide.

Winoto, G. N., \& Pujiyono, A. (2011). Pengaruh Dana Zakat Produktif terhadap Keuntungan Usaha Mustahik Penerima Zakat (Studi Kasus BAZ Kota Semarang). Universitas Diponegoro. 
WZF Research and Development in Collaboration with BAZNAS Center of Strategic Studies. (2021). World Zakat Performance Index: A Conceptual Framework. Center for Strategic Studies - National Board of Zakat (Puskas BAZNAS). 